\title{
Contended Bodies
}

\section{Witchcraft and Gender in the Early Modern Germanlands}

AUTHOR: Leyla Pavão Chisamore

EDITED BY: Kendall Fisher, Julian Matheson, and Marisa Coulton

These tracts [on magic] did agree one point, namely, that the greatest danger as well as the single most powerful sign of humankind's special status was its free will. Only free will drove men and women to seek knowledge, be it of good or of evil. Paracelsus concurred; he agreed that free will was at once humankind's greatest gift and its most precious divine burden.

-Gerhild Scholz Williams, Defining Dominion, 1995

In this examination of discourses on magic and witchcraft, German Literature Professor Gerhild Scholz Williams emphasizes the complex relationship between the seemingly disparate experiences of institutionalized religious belief and illicit, privately conducted magical practices. The occult popular throughout the medieval period as lay religious life incorporated a range of diverse religious practices, including Christian sacramental systems, rural mystical traditions, and undercurrents of folk practices ranging from charms to exorcisms. ${ }^{1}$ Here, the religious transition and subsequent political turbulence of the Reformation produced a Protestant denial of these manifestations of spiritual experience while also expanding interfaith anxieties surrounding witchcraft practices and heresy.

This essay will examine the development of early modern definitions of witchcraft and its production into a gendered and illicit programme by shifts in the theological and political landscape continental Europe. Emphasis will be placed on the early modern Germanlands, and will be informed by broader religious, cultural, and social unrest throughout the European context. This paper will follow historian Ronald Hutton's global definition of witchcraft, wherein a witch possesses five key characteristics: the ability to cause harm by uncanny means, to act as internal threat to a community, to function within a tradition, to be evil, and the ability to resist counter-attacks. ${ }^{2} \mathrm{~A}$ contemporary feminist framework will be used to examine witchcraft in the Reformation Germanlands, this framework will address the existing gaps in the historiography. Emphasis will be reassigned not only to female and male witches (and so offer agency to the historical subjects), but also to emphasize inherited medieval understandings of the sexuality and the gendered body.

Medieval notions of magic were central to the lay religious experience which placed substantial emphasis on materiality in faith (e.g., sacramental items, saintly relics). These theoretical underpinnings preceded the loss of material practices instigated by the emergence of theological shifts within Reformer movements and so impacted wider knowledge of magic and witchcraft. Both ecclesiastical authorities and the wider public understood licit magic, or Scientia magica, could "heal the rift between themselves and their Creator, between body and soul [which] always represented the institutionalized, scientific transgression of boundaries." ${ }^{3}$ In this, magic as an idea was inextricable from power relations, differentiated between the phrases magic and mysticism themselves: individuals who exercised control over the supernatural and individuals who surrender control to the supernatural, respectively. ${ }^{4}$ 
In this distinction, humanity's free will and the popular Augustinian position toward an inherent inclination to sin produced a potentially corruptive nature to all emphatically magical practices.

Scientia magica became maleficum, or bad magic. Socio-religious and gendered frameworks of the period also imbued a 'universal knowledge' that extended to the peasant classes within which certain categories of individuals were inherently more susceptible to sin and its consequences. This definition predominantly encompassed women, Jewish minorities, and many physicians of the period. ${ }^{5}$ Concepts of religious deviance and moral corruption acted simultaneously, and thereby produced magical potential for realized social harm beyond the existing moral dangers associated with female sexuality and Judaism. In each of these cases, existing prejudices established a lack of tolerance which were, in turn, rampantly reproduced as accusations with the emergence of the initial mass witchcraft panic in late sixteenth century Trier in the Germanlands. ${ }^{6}$

While local collective memory and rumour circulation almost exclusively produced accusations of witchcraft, these allegations necessitated the production of mala fama (bad reputation) essential for witchcraft to take hold, the widespread parallel between early modern accusations of witchcraft and perceived Jewish violence merit acknowledgement. ${ }^{7}$ Such medieval theories extended well into persecution throughout the early modern period, and propagated the dangers of (primarily female) witches and Jewish peoples alike who committed infanticide, performed blood-letting, and practiced host desecration. ${ }^{8}$ Through these descriptors, moral degradation became associated with social deviance in multiple capacities. For example, the extreme dangers included a programme of gendered and ethnocultural prejudice by which locals and ecclesiastical authorities bore a watchful eye for transgressions committed by nonconforming women, Jewish peoples most explicitly.

If the deviance that begot sin necessitated both individual susceptibility and free will, then cultural regulations deemed that authorities mitigated the potential social dangers formed by social deviance. This stringent regulation, which underscored the possibilities of extreme immoral behaviour included binary gender definitions. Church authorities defined negative behaviour to assert the positive values and corresponding benefits of homogeneity. ${ }^{9}$ Both internalized and communally policed at a local level, this gendered behavioral code contributed to accusations which increasingly led to interventions and trials with the burgeoning witchcraft panics. ${ }^{10}$ The convenience of witchcraft in this context was also reliant on its ability to unify non-conformist behaviours into a singular package of punishable deviance through which control was widely asserted. ${ }^{11}$ Moralistic violence was a key tool to reassert spiritual authority and political control.

The development of the printing press in both literary and art practices was significant to the spread of religious dissent for reformer movements, but also in the establishment of witchcraft knowledge and tropes. ${ }^{12}$ Historian Lyndal Roper addresses early images of witchcraft produced during the latefifteenth century which condemned witchcraft with more intensity than produced heretofore. ${ }^{13}$ Earlier works were sensual, produced for entertainment, or rooted in pagan, classical imagery. ${ }^{14}$ She questions the change that occurred during the period to allow for such a contrast in imagery within a matter of decades. In answer, the late-fifteenth century publication, Malleus Maleficarum, written by inquisitors Henry Institoris (known also as Heinrich Kramer) and Jacob Sprenger, was central to the design of this early modern witch as used in their investigations of heresy in the Rhinelands and Upper Germanlands. ${ }^{15}$ Translated as Hammer of the Witches, this guide defined the stereotypical imagery of haggard women on broomsticks and nude dancing women at the Witches' Sabbath, later reproduced extensively following its printing and widespread distribution. Both accessible literature and prints incorporated the developing witchcraft tropes. Bodin aimed his exclusive vernacular work, 
Démonomanie des sorciers (On the Demon-Mania of Witches) for example, at a wide audience and loosely structured around the then century-old Malleus, attesting to its widespread popularity. ${ }^{16}$ Frequently, these tropes borrowed from paganism and mimicked images of personified Envy - the vice central to female witches in the Malleus. ${ }^{17}$ This production of imagery inserted itself into largely illiterate lay communities and altered perceptions of witches to clearly denoted visible markers. In doing so, Germany and the Rhinelands saw a shift in public perception which influenced local suspicions, rumours and, in turn, accusations. Following its distribution and proceeding artistic renditions, individuals formally charged with maleficia increased notably over period. ${ }^{18}$

Additionally, Malleus Maleficarum not only extensively defined witchcraft through formal legislation including a witch's qualities, rituals, and methods of propagation, but further denoted structured local opportunities for personal resistance and hunting within the inquisitorial system. ${ }^{19}$ This widespread popularity was maintained well into the seventeenth century as Hans Broedel's research shows: it was "printed fifteen times between 1486 and 1520 , and went through another nineteen printings during the fiercest period of witch persecutions in Europe between 1569 and 1669."20 Following the Council of Trent, an increased emphasis on assertion of Catholic identity placed ecclesiastical authorities on the offensive as they asserted authority and highlighted potential differences between developing reform movements and Catholicism to limit heresy. Inquisitorial trials became popular throughout continental Europe with primarily Catholic regions such as Spain, which saw extensive investigations into heresywitchcraft among them. Improper gender behaviour allowed for locals to police family or neighbours at trials, and allowed an audience to ensure a ritualistic public shaming. ${ }^{21}$ While prosecutors exercised autos-de-fé and other punitive measures, many limited the trials as the court shamed the accusers to assert Church dominance. ${ }^{22}$ This institutionalized condemnation of witchcraft was developed into a secular crime, which, in turn, bolstered Catholic authority in both moral and temporal capacities.

Just as inquisitors reframed witchcraft in the local psyche, Malleus constructed witchcraft as a formal ceremony with the devil (through his demons) on earth and conceptually amalgamated medieval folk belief with a theological worldview. ${ }^{23}$ This delineation between magic and mysticism was then formally erased in the European context, which favoured instead a singularly structured anti-Church through which already susceptible individuals converted to witchcraft. Ronald Hutton notes the anomalous nature of the European context as it is the sole continent to frame witchcraft through this exclusive binary as the Malleus develops: "a heretical anti-religion, dedicated to the worship of an embodied principle of evil in the cosmos." ${ }^{24}$ Constructed in this work as this formal ceremony antithetical to the Mass, the Witches' Sabbath included a mirrored desecration of the sacramental communion:

The witch enters a covenant with Satan who mark her and draws blood; the Devil then provides a familiar who regularly sucks blood from the resulting wound, drawing it into a teat this inverted Eucharist is designed to 'put her in mind of' the original transaction. ${ }^{25}$

Catholics and Protestants alike condemned the believed ceremony with varied emphasis; Catholics focused on the desecration of ritual and Protestants focused on the desecration of the covenantal relationship between the individual and God.26 Through unusual emphasis on an institutional opposite, Sprenger and Jacob constructed a far more dangerous conversion by which the establishment of numerous reform movements paralleled in attitude those satanic heresies found in witchcraft. ${ }^{27}$ The sinfulness of both beliefs became imbued as not only anti-Catholic but distinctly evil, and therefore merited attack. As such, later inquisitorial projects relied heavily upon the Malleus. 
While medieval practices of witch resistance favoured protectiverituals/sacramentals, benevolent magic and adjustment of social relations, the early modern witch approach commonly used literal counter-attacks of expulsion, trials, and execution. This was particularly apt as anxieties surrounding crop failure and political change increased toward the late fifteenth century. ${ }^{28}$ Beginning in the $1580 \mathrm{~s}$ and in tandem with the witch panics, there were only two successful harvests over the course of the decade. ${ }^{29}$ This statistical analysis revealed the addressed crop failures contributed to further suffering and increased anxiety. It is in this period that mass witch-hunts developed primarily in Western Germany under the ecclesiastical authority of archbishop-electors, including the Archbishops of Trier, Mainz, and Cologne. By the mid-1580s and declining by 1639 , they "accounted for over one-third of all executions for witchcraft in present-day Germany, and for almost a quarter of all such executions in Europe," or approximately 6,000 accusations and 1,000 executions at its peak. ${ }^{30}$ Executions continued despite the severe decline in mass trials and, by the mid-eighteenth century authorities arrested approximately 110,000 individuals in total and executed roughly $6,000 .{ }^{31}$

Kramer and Sprenger, in writing the Malleus, inserted an intense misogyny into the work, and as consequence, made an inextricable link between women and the crime of witchcraft, which further incited violence. The language of the work incorporates this explicit intention as maleficum denotes the feminine plural ending rather than the more commonly used male forms of the period. ${ }^{32}$ Additionally, the Malleus at times includes the Latin male form wicca rather than the female wicce in reference to male witches throughout and so bolstered their intentional selection to associate witchcraft with the feminine. ${ }^{33}$ It is suggested earlier witchcraft historiography merits critique for its dismissal of this linguistic selection. ${ }^{34}$ Textual evidence for doing so dismisses evidence in favour of scholarly agendas or imagined empiricism. In either case, the subjects of the trials saw gendered removal from the accepted canon. This scholarly project is rather to navigate the ways in which theories of gender and ecclesiastical authorities acted in tandem, to produce accurate histories for those subjects thereby to illuminate a traumatic past.

To extend this statistical analysis into gender and acknowledge the distribution of witchcraft accusations as geographically contingent, areas informed by Malleus like Germany, Basel, Hungary, and Denmark saw 70 per cent to 90 per cent of females accused, which was further reflected in the trials. ${ }^{35}$ The predominance of female witches extended also to England and Scotland where the Malleus was not as dominant, but rather informed through gendered hierarchies. As the witchcraft panic began to establish itself on the continent, the Scottish Reformation saw political instability and rebellion due to contention that surrounded female rulers in Britain. These regional variances saw gendered accusations in the printed writings of John Knox, rather than Kramer and Sprenger. Regional conceptions of gender drove witchcraft accusations in much the same manner as textual direction. Such contingencies also expanded to cultural values that emanated from regional and even local centres and so there was variability even within a single nation. For example, trial records from Normandy (73 per cent) and Iceland (92 per cent) showed the majority of those accused were male. ${ }^{36}$ In these factual analyses, the detrimental impact of gender and local witchcraft beliefs, paired with the influence of variables such as climate and print, became visible in their regional consequences.

Inherited scientific and scholarly discourses perpetuated throughout the medieval period influenced such discussions of gender. The dominance of 'humoral' theory instilled essentialist hierarchical understandings of the gender binary system. Physicians believed the body was consistently balancing four fluids (blood, phlegm, yellow bile, and black bile), and assigned these qualities to gender as well. 
Women were predominantly characterized as cold and wet and situated below men, who were hot and dry. These frameworks were gendered most clearly in the natural philosophical text, De secretis mulierum, written under the pseudonym Albertus Magnus, published in the late-thirteenth to early-fourteenth centuries. ${ }^{37}$ Produced as a broad medical understanding of the female body intended to pair with official gynecological guides, it has undercurrents of misogyny and perpetuates concepts of female biological inferiority, sinful disposition, and a physically and emotionally corruptive nature. ${ }^{38}$

This work understands women as "not only as insufficiently formed blood, but as bodies which reputedly lose such blood." 39 De secretis frames this permeability as weak and incomplete compared to the integral male body and so is inherently inferior. ${ }^{40}$ This understanding purportedly allowed women a closer relationship to nature and to the supernatural, which extended to intervention by the Holy Spirit or the devil. ${ }^{41}$ Early modern society perceived women to be more readily susceptible to sin and witchcraft which extended this understanding into the public sphere. That is, the surrounding world bound the body, by which one's socio-cultural or political status were defined — the implications then possessed very real consequences. ${ }^{42}$ The female body in a social capacity was simultaneously inferior and profoundly dangerous. Commentator A in De Secretis notes its dangers as follows:

Women are so full of venom in the time of their menstruation that they poison animals by their glance; they infect children in the cradle; they spot the cleanest mirror; and whenever men have sexual intercourse with them they are made leprous and sometimes cancerous. ${ }^{43}$

In large part, patriarchal anxieties produce early modern witchcraft theories as in De secretis, which later informs Kramer and Sprenger in their writing of the Malleus. Scholz Williams highlights in Defining Dominion that "the dread of being sexually vulnerable to witchcraft, to satanically induced castration, was intensified by the image of the disgendered male, whose sexual organs may have been pulled inside his body, making him appear female." ${ }^{4}$ Kramer reiterates this feminized danger, paralleling $D e$ secretis theories, citing intentional threats to masculinity on the part of women to prevent conception, induce miscarriages, inflict disease as "[God] punished the people of Israel" and control or remove male sexual organs. ${ }^{45}$ Inciting localized fear continues the project of proper behaviour and consolidation of power by ecclesiastical authorities.

Social marginalization and poverty perpetuated gendered divisions of morality and their corresponding witchcraft accusations in the European context. This marginalization revealed new community members, as well as both old and young women without a traditional family structure, and drew public concern regarding maleficum more readily. While this sustained suspicions, it was immoral behaviour which produced the collective memory and rumour to organize formal accusations. It was so-called uncontrolled femininity that included lustfulness, aggression, and a general lack of propriety. ${ }^{46}$ Most notably, the criminalization of sexual activity also became more rigorous and accusations extended beyond the dominant tropes of older women to include young women in relation to witchcraft. ${ }^{47}$ While the majority of secular crimes such as arson or theft left women under patriarchal authority through family units as brothers or fathers who took their place in court, the moral offense of maleficia became one of the few crimes with which the court charged women individually. ${ }^{48}$ In the trials, there was limited representation for sex-specific crimes and the accused were unable to do more than seek amends through social adjustment. ${ }^{49}$ Male authority, however, extended into their legislative rights and allowed for accused males to defend themselves in court, further competing with local and largely male peers to seek dismissal.

Male witches, in contrast, frequently played central roles in their communities yet perverted 
the ordered control essential to defining masculine bodies and character..$^{50}$ These offenses could include neighbourly disputes, "aggressive economic habits," public drunkenness, mismanagement of the family unit, and/or abuse of power..$^{51}$ Accusers of male witches were primarily men in the community who exacerbated local contentions. ${ }^{52}$ Considering De secretis mulierum, male witches subverted essential gender characteristics and so lost the mastery essential to hegemonic masculinity of the period which was economic, emotional, and physical. Here, the accused places themselves in proximity to their counterparts of the female witch. ${ }^{53}$

Due to this uncontrolled body, male witches were theoretically castrated and frequently referred to as "blind one" and in possession of "a heavy stench." ${ }^{44}$ As moods and sensory domains were also categorically organized within this framework, sight was the highest sense and so associated with men and scent being hierarchically lower was associated with women. ${ }^{55}$ This language drew heavily upon female qualifiers which emphasized weakness and produced a semantic feminization paralleling his social decline. ${ }^{56}$ Despite this, male witches retained physical masculinity and according to inquisitor Heinrich Kramer, possessed the authoritative capacity to preach the "demonic doctrines" of witchcraft where female witches were deemed incapable. ${ }^{57}$ The privileges afforded by their embodied status secured the fear of male witches, and thus a potentiality for creating and guiding social unrest. ${ }^{58}$ This encompassed not only practices of witchcraft, but also Protestant reform movements. While female danger was individual (e.g., castration, possession) or isolated to their local community (e.g., crop failure), male witches carried the potential to spread doctrine and so infect both individual communities and wider regions through their power, potentially threatening ecclesiastical authority.

Kramer's inquisitional project, the Clippeum, continues in paralleling the anti-Church of witchcraft with reformer heresies. The work formalizes a satanic covenant through a demonic ceremony exclusive to men. The devil arrives at a designated location in the form of a fly and the Waldenians (here referring broadly to any heretical movements) swallows him, gaining literacy in Latin and the vernacular, as well as the necessary doctrines to preach and gain converts. ${ }^{59} \mathrm{He}$ states:

The Church is shattered by these most bitter afflictions... through internal dissensions in terms of the expansion of heresies, especially these two, namely the Waldensians and witches... These two heresies, one by which damage is caused to souls, and the other by which bodily damage is caused ... make] the injuries to the Catholic faith grow stronger...

This conflation allowed for the justification of confessional state control and used the threat of heretical corruption to punish deviance. Associating literacy with heresy underscored reformer approaches on Scripture and individual engagement with the text, as well as its dangers. Developments in the printing press and an increase in lay literacy stood as direct threats to ecclesiastical dominance. This became more prominent as reformer movements intensified and emphasis upon Scripture expanded. In this European context, the Malleus' equalizing of heresies produces a singular threat of evil in direct opposition to Church authority.

As reformer movements became established, there were variable Protestant reactions to witchcraft dependant. Catholics and Lutherans conducted trials and executions in mass witch-hunts throughout the panic as each associated witchcraft with the other. ${ }^{61}$ Militaristic regions that favoured Calvinism and Zwinglism regulated local behaviour through extensive focus on civilian responsibility, and therefore were less lenient with accused witches than their non-militaristic counterparts. A belief in predestination also framed reputation and local rumour as signifiers of potential corruption. Comparatively, Anabaptists were more tolerant and favoured social exclusion over execution. Due to 
the direct relationship between confessional statebuilding and the necessary binary of the Church and anti-Church, these theories are most likely. ${ }^{62}$ Anabaptists emphasized a sinful world, focusing on the internal community and its behaviour. Witchcraft in its European manifestation simply did not fit into the Anabaptist worldview. The Anabaptist rejection of infant baptism, or "unexorcised' individuals," denoted an additional level of vulnerability to sin and thus to witchcraft. $^{63}$ Frequently, Anabaptist interrogations featured accusations of relations with the devil not unlike those of witchcraft. ${ }^{64}$ Those Anabaptists accused of heresy in inquisitorial trials were often tried under the same courts as witches within the same week. ${ }^{65}$ Anabaptist levels of tolerance were exceptional for the period and this disposition corresponds with both the extent of their own persecution and their communal selforientation which situated Anabaptism outside of the developing confessional state.

The mass witch-hunts which began through state-building projects and local anxieties, declined as the formal confessional state ceded some control to religious plurality. Among the factors was an increase in judicial skepticism which more stringently interrogated local rumours, heretofore nearly unquestioned. ${ }^{66}$ This added further difficulties in establishing guilt and so the regularity of trials waned. Just as authorities investigated these rumours in further detail, evidence decreased throughout Europe as urban development and migration limited the potential for shifting collective memories to establish ongoing suspicions. ${ }^{67}$ But most notably, the discussed religious pluralism of burgeoning central governments during the midseventeenth century opened cultural expectations which to some extent normalized earlier definitions of deviance. ${ }^{68}$ As anxieties declined and public perceptions shifted, so too did the primacy of the confessional state.

Although medieval folk tradition normalized witchcraft and its many economies of the sacred, it was through institutional intervention seeking consolidation of confessional authority that magic developed into a gendered and illicit programme. Heinrich Kramer and Jacob Sprenger perpetuated such dualistic conception in the Malleus Maleficarum and so perpetuated the violent frameworks undertaken as anxieties rose both locally and politically. Assertions of homogeneity in gendered, moral, and religious behaviour manifested the mass violence of European growing pains. While gendered and religious bodies saw themselves contested over the decades, it ultimately settled into a pluralized if not emptier continent.

\section{ENDNOTES:}

\section{Epigraph}

Gerhild Scholz Williams, Defining Dominion: the discourses of magic and witchcraft in early modern France and Germany (Ann Arbor: University of Michigan Press, 1995), 50.

\section{Endnotes}

1. James Stayer, "The Reform of Religion," in Course Reader: HIST341 The Reformation, ed. R. Bailey (Kingston: Queen's University, 2017), 6. 2. Ronald Hutton, The Witch: A History of Fear, from Ancient Times to the Present (London: Yale University Press, 2017), 10-35.

3. Gerhild Scholz Williams, Defining Dominion: the discourses of magic and witchcraft in early modern France and Germany (Ann Arbor: University of Michigan Press, 1995), 49.

4. Ibid., 14.

5. Ibid., 49.

6.William Monter, "Witchcraft, Confessionalism and Authority," in The Witchcraft Reader, ed.

Darren Oldridge (London; New York: Routledge, 2008), 201.

7.Hans Broedel, "The Malleus Maleficarum and the Construction of Witchcraft," in The Witchcraft Reader, ed. Darren Oldridge (London; New York: Routledge, 2008), 45-6.

8. Ibid., 45.

9.Christina Larner, "The Crime of Witchcraft in Europe," in The Witchcraft Reader, ed. Darren Oldridge (London; New York: Routledge, 2008), 
166.

10.Broedel, "The Malleus Maleficarum and the Construction of Witchcraft," in The Witchcraft Reader, 45-6.

11.Larner, "The Crime of Witchcraft in Europe," in The Witchcraft Reader, 166.

12. Lyndal Roper, The Witch in the Western Imagination (Charlottesville: University of Virginia Press, 2012), 37.

13. Ibid., 2.

14. Ibid., 2.

15. Heinrich Kramer and James Sprenger, Malleus Maleficarum, trans. Christopher S. Mackay

(Cambridge: Cambridge University Press, 2006).

16. Ibid., 28.

17. Ibid., 24, 93.

18. Herzig Tamar, "Flies, Heretics, and the Gendering of Witchcraft," Magic, Ritual, and Witchcraft 5, no. 1 (2010): 61.

19. Kramer and Sprenger, Malleus Maleficarum.

20. Broedel, "The Malleus Maleficarum and the Construction of Witchcraft," in The Witchcraft Reader, 43.

21. Maureen Flynn, "Mimesis of the Last Judgment: The Spanish Auto De Fe," in The Sixteenth Century Journal 22, no. 2 (1991): 281-2. 22. Ibid., 281.

Autos-da-fé were a popularized form of execution, particularly throughout Inquisitorial Spain, wherein heretics were publicly tried and, for many, executed by burning at the stake in public ceremony.

23. Broedel, "The Malleus Maleficarum and the Construction of Witchcraft," in The Witchcraft Reader, 47.

24. Hutton, The Witch, 41.

25. Oldridge, The Witchcraft Reader, 278-9.

26. Ibid., 132.

27. Tamar, "Flies, Heretics, and the Gendering of Witchcraft," 57.

28. Hutton, The Witch, 5-35; Monter, "Witchcraft, Confessionalism and Authority," in The Witchcraft Reader, 202.

29. Monter, "Witchcraft, Confessionalism and Authority," in The Witchcraft Reader, ed. Darren Oldridge (London; New York: Routledge, 2008),
201.

30. Ibid., 202.

31. Lara Apps and Andrew Gow, Male Witches in Early Modern Europe, (Manchester; New York: Manchester University Press, 2003), 25.

32. Ibid., 3.

33. Ibid., 8-9.

34. Ibid., 112.

35. Oldridge, The Witchcraft Reader, 248.

36. Apps and Gow, Male Witches in Early Modern Europe, 45.

37. Helen Rodnite Lemay, Women's Secrets: a translation of Pseudo-Albertus Magnus' De secretis mulierum with commentaries (Albany: State University of New York Press, 1992), 1. 38. Ibid., 1.

39. Bettina Bildhauer, Medieval Blood (Cardiff: University of Wales Press, 2006), 91.

40. Ibid., 93-96.

41. Sarah Ferber, "Ecstasy, Possession, Witchcraft," in The Witchcraft Reader, ed. Darren Oldridge (London; New York: Routledge, 2008), 230.

42. Bildhauer, Medieval Blood, 96.

43. Lemay, Women's Secrets, 60.

44. Scholz Williams, Defining Dominion, 73.

45. Kramer and Sprenger, Malleus Maleficarum, 146.

46. Oldridge, The Witchcraft Reader, 250.

47. Larner, "The Crime of Witchcraft in Europe," in The Witchcraft Reader, 254.

48. Ibid., 175.

49. Ibid., 175.

50. Oldridge, The Witchcraft Reader, 250.

51. E.J. Kent, "Masculinity and Male Witches in Old and New England" in The Witchcraft Reader, ed. Darren Oldridge (London; New York: Routledge, 2008), 293.

52. Ibid., 298.

53. Ibid., 297.

54. Apps and Gow, Male Witches in Early Modern Europe, 129-130.

55. Ibid., 129-130.

56. Ibid., 130.

57. Tamar, "Flies, Heretics, and the Gendering of Witchcraft," 67. 
58. Kent, "Masculinity and Male Witches in Old and New England" in The Witchcraft Reader, 291. 59. Tamar, "Flies, Heretics, and the Gendering of Witchcraft," 68-69.

60. Ibid., 57.

61. Oldridge, The Witchcraft Reader, 132.

62. Ibid.,, 132.

63. Gary K. Waite, "Anabaptists and the Devil," in The Witchcraft Reader, ed. Darren Oldridge

(London; New York: Routledge, 2008), 162.

64. Ibid., 160.

65. Ibid., 133.

66. Oldridge, The Witchcraft Reader, 338.

67. Ibid., 339.

68. Ibid., 338.

\section{BIBLIOGRAPHY:}

Apps, Lara and Andrew Gow. Male Witches in Early Modern Europe. Manchester; New York:Manchester University Press, 2003.

Bailey, Richard, ed. Course Reader: HIST341 The Reformation. Kingston: Queen's University, 2017.

Bildhauer, Bettina. Medieval Blood. Cardiff: University of Wales Press, 2006.

Flynn, Maureen. "Mimesis of the Last Judgment: The Spanish Auto De Fe." The Sixteenth Century Journal 22, no. 2 (1991): 281-97.

Hutton, Ronald. The Witch: A History of Fear, from Ancient Times to the Present. London: Yale University Press, 2017.

Kramer, Heinrich and James Sprenger. Malleus Maleficarum, translated by Christopher S. Mackay. Cambridge: Cambridge University Press, 2006.

Lemay, Helen Rodnite. Women's Secrets: a translation of Pseudo-Albertus Magnus' De secretis mulierum with commentaries. Albany: State University of New York Press, 1992.
Oldridge, Darren, ed. The Witchcraft Reader. London; New York: Routledge, 2008.

Roper, Lyndal. The Witch in the Western Imagination. Charlottesville: University of Virginia Press, 2012.

Scholz Williams, Gerhild. Defining Dominion: the discourses of magic and witchcraft in early modern France and Germany. Ann Arbor: University of Michigan Press, 1995.

Tamar, Herzig. "Flies, Heretics, and the Gendering of Witchcraft." Magic, Ritual, and Witchcraft 5, no. 1 (2010): 51-80. 